\title{
Experimental investigations and comparison of various MPPT techniques for photovoltaic system
}

\author{
ANKUR KUMAR GUPTA $^{1, *}$, YOGESH K CHAUHAN ${ }^{2}$ and TANMOY MAITY ${ }^{1}$ \\ ${ }^{1}$ Mining Machinery Engineering Department, Indian Institute of Technology, Indian School of Mines (IIT, \\ ISM), Dhanbad 826004, India \\ ${ }^{2}$ Electrical Engineering Department, Kamla Nehru Institute of Technology, Sultanpur 228118, India \\ e-mail: ankurradikal@gmail.com; chauhanyk@yahoo.com; tanmoy_maity@ rediffmail.com
}

MS received 5 May 2017; revised 24 November 2017; accepted 14 December 2017; published online 5 July 2018

\begin{abstract}
This paper deals with Matlab/Simulink and experimental investigations of various maximum power point tracking (MPPT) techniques namely incremental conductance (Inc), perturb and observation (P\&O), constant voltage control (CVC) method, and introduction of a novel reference power (Pref) method for extracting the maximum power from the solar photovoltaic (PV) system. The complete system model along with these MPPT methods are developed in Matlab/Simulink and simulation results are obtained during sudden increase in irradiation of $1000 \mathrm{~W} / \mathrm{m}^{2}$, and verified experimentally. These MPPT methods are also implemented on Inverse-Sepic converter, which claims to extract maximum power from the PV system. Various experimental observations are taken to access the performance of these MPPT techniques such as settling time of the full load current under sudden exposure of irradiation level of $1000 \mathrm{~W} / \mathrm{m}^{2}$, performance during step increase in irradiation level (from $500 \mathrm{~W} / \mathrm{m}^{2}$ to $1000 \mathrm{~W} / \mathrm{m}^{2}$ ) and vice versa. Extensive results are taken to compare these methods. The proposed Pref method is found to have lowest settling time to stabilize the load current as $520 \mathrm{~ms}$, whereas, Inc method takes $1.24 \mathrm{~s}$. Further, the efficiency of Inverse-Sepic converter with Pref method achieves the highest efficiency of $95.26 \%$, whereas, it extracts lowest efficiency on same input as $90.77 \%$ with P\&O method. The overall performance of the proposed Pref method is found to be superior as compared to other discussed MPPT methods as verified by experimental results.
\end{abstract}

Keywords. DC-DC Converter; perturb \& observation (P\&O); incremental conductance (Inc); constant voltage control (CVC); photovoltaic (PV) cell; renewable energy resources (RERs).

\section{Introduction}

In the last two decades, the solar energy source played a vital role in the environment protection. Thus the renewable sources should be increased so that the generation of electricity will be provided without any adverse impact on environment. Renewable energy plays a vital role in the production of electricity. United States organized a firm called EIA (Energy Information Administration) to gather the hazards caused by the non-renewable sources. They proved that non-renewables sources can cause greenhouse effect [1]. Normally non-renewable sources include plastics, oil, coal and uranium. These resources are not easy to degrade. So, they causes more hazards to the environment. Fossil fuels are leading to global warming. Nitrous oxide is released during the burning of fossil fuels. That causes allergy to the people living nearby [2]. The pollution not only affects the people but also it causes acid rain, photochemical pollution and release greenhouse gases [3]. The

*For correspondence
UCS (Union of Concerned Scientists) researched about the non-renewable sources and stated that it creates damage to the Ozone layer. In 2016, a report was prepared by mentioning that more than 90 million drums of oil per day were consumed globally. Year by year oil usage is increasing, that leads to increased utilization of non-renewable resources [4]. The production cost of solar photovoltaic has been decreasing considerably in the last couple of years. $\mathrm{PV}$-module is nowadays available in a packaged structure that was connected with series and parallel combination of solar cells [5-7].

PV modules are commonly used in distributed power generation and also in centralized power generation. It is noise and pollution free power generation. On the other hand, there are various demerits of PV module such as more expensiveness and lack of full electricity generation during cloudy days. In order to overcome the limitations in PV module, the technique is developed namely MPPT [8], which is applied to control the DC to DC (direct current) converter [9]. The MPPT technique manages the electronic interface by matching the source resistance and the load 
resistance. The MPPT technique is followed by solar photovoltaic to gain the maximum power [10]. The $\mathrm{P} \& \mathrm{O}$ technique is executed by means of identifying the present solar power and adjust the duty cycle for trying to track the maximum power. PV systems are connected in different configurations, based on the required load current and voltage [11]. It is based on the relationship with the external grid, battery banks, inverter systems and electric load. The problem addressed by MPPT is based on the power transfer capability from different solar cells, which depends on sunlight which is falling on the solar panels and characteristics of the electric load. The efficiency of the power transfer will change according to sunlight and load characteristics. Complex relationship exists between the solar cells with total resistance and temperature [12]. It produces the non-linear output and hence non-linear I-V curve which is used to analyze the efficiency. There are many methods which are involved in tracking the maximum power point (MPP) and some of them are Perturb \& Observe method (P\&O), Incremental conductance method (Inc), Fractional Open Circuit voltage (FOCV) method, Fractional short circuit current (FSCC) method, CVC method, etc.

The objectives of this paper are as follows:

- Development of simulation model of system, which comprises of mainly solar PV, Inverse Sepic DC-DC converter along with $\mathrm{P} \& \mathrm{O}$, Inc, $\mathrm{CVC}$ and novel Pref MPPT methods.

- Design and development of Inverse-Sepic DC-DC converter.

- Experimental implementation of these MPPT methods on Inverse-Sepic converter and validation of simulation results using hardware results.

- Comparison of novel Pref method with other implemented MPPT methods under different operating conditions.

\section{System description}

The system under consideration consists of various MPPT methods using the Inverse-Sepic Converter, is illustrated in figure 1 . The load voltage and current are controlled by this converter. The four MPPT methods are used to drive this converter one by one. The voltage and current of the solar panel are sensed and duty cycle of inverse sepic converter is obtained by using different MPPT ( $\mathrm{P} \& \mathrm{O}$, Inc, CVC and Pref) methods. The feedback system of the converter is associated with the load.

The power achieved in tracking involves the load conditions and the atmospheric conditions. The oscillations are maintained low during the tracking operation [13]. There are three control variables that are involved in the tracking procedure which include: finding out the value of duty cycle, current and voltage. There are various types of converters that are practiced in the tracking methods and

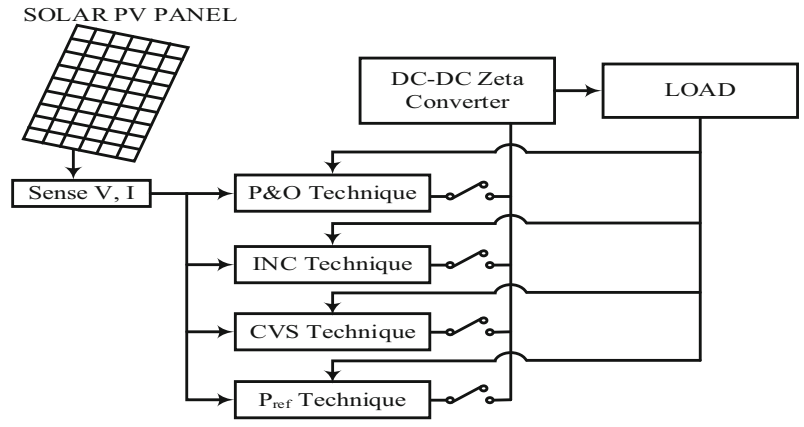

Figure 1. Schematic arrangement of testing system.

they include buck converter, boost converter, buck-boost converter, and Inverse-Sepic converter which are used to increase or/and decrease of the voltage [14]. Here InverseSepic Converter circuit is used in the power tracking operations. The $4^{\mathrm{TH}}$ order DC to DC converter which is made up of 2 inductors and 2 capacitors is modelled as Inverse-Sepic converter. This type of converter is flexible for both step-up and step-down mode of operation. The Inverse sepic converter is also known as zeta converter. The Inverse-Sepic converter consists of an electronic circuit that converts the level of voltage from one state to another state. For any kind of photovoltaic systems, the Inverse-Sepic converter is used to maximize the power [15-17].

\section{Implementation of various MPPT techniques}

A brief description about MPPT technique namely $\mathrm{P} \& \mathrm{O}$, Inc, CVC and novel Pref method MPPT techniques are discussed in this section.

\subsection{P\&O MPPT technique}

Generally, photovoltaic modules (PVM) are widely used in energy storage systems and water pumping [18]. The flowchart of P\&O MPPT method is shown in figure 2. The steps are as follows.

(i) Measure the values of voltage and the current, respectively at $\mathrm{k}^{\text {th }}$ and $(\mathrm{k}-1)^{\text {th }}$ instant as $V_{P V}(k), I_{P V}(k), V_{P V}(k-1), I_{P V}(k-1)$.

(ii) Do the calculation of $\mathrm{P}_{\mathrm{PV}}(\mathrm{k})$ as $P_{P V}(k)=$ $V_{P V}(k) \cdot I_{P V}(k)$ and $P_{P V}(k-1)=V_{P V}(k-1) . I_{P V}(k-1)$.

(iii) Check for the condition listed below

$$
P_{P V}(k)>P_{P V}(k-1) .
$$

(iv) If yes then increase the operating voltage, otherwise decrease the operating voltage.

According to this loop, the power will increase or decrease and move near the max power point [19]. The 


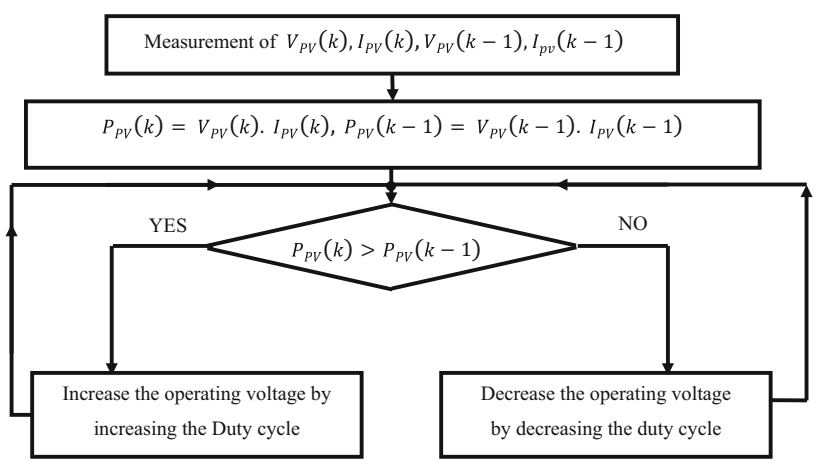

Figure 2. Main steps in flow chart of P\&O method.

operation consists of arrangement of feedback parameters. Normally this method perturbs the system's operating point that causes the fluctuations in the MPP voltage. The voltage and current fluctuate simultaneously. The step size must be maintained higher so that the noise factor can be minimized correspondingly.

3.1a Limitations undergone in $P \& O$ method: If the step size is not maintained high, then results in slowing down of the system response. The system response is affected with respect to the sudden change of irradiance and temperature. If there is any kind of fluctuations arise then the result obtained will have no stability in response.

\subsection{Inc MPPT technique}

Normally, Inc technique is used for the power tracking quickly in solar power system. The performance of Inc method is very precise in controlling the voltage in varying

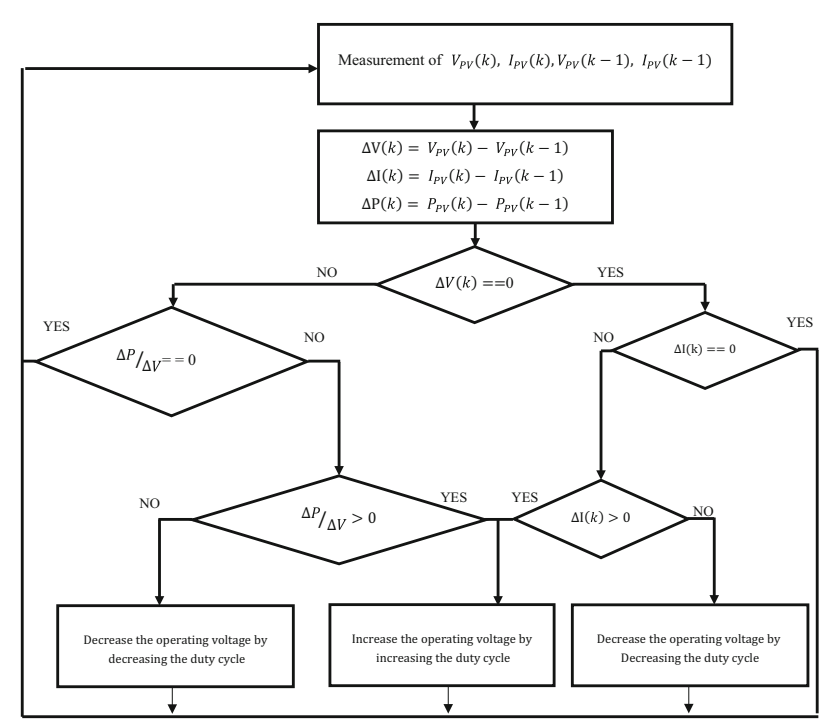

Figure 3. Main steps in flow chart of Inc method. atmospheric conditions [20]. There are two types of step size that are implemented in the Inc method, namely: Fixed step-size and Variable step-size. Compared to other tracking techniques, Inc is considered as the high accuracy tracking method. Good adaptability and maintenance of steady state are the two main features of Inc method [21]. The flowchart is shown as figure 3 . The equations involved in the Inc method is shown below,

$$
P=\left(V_{p v} \times I_{p v}\right)
$$

$$
\text { For MPP, } \begin{aligned}
& \mathrm{dP} / \mathrm{dVpv}=\mathrm{Ipv}+\mathrm{Vpv}(\mathrm{dIpv} / \mathrm{dVpv}) \\
&=\mathrm{Ipv}+\mathrm{Vpv}(\Delta I / \Delta V) \\
& \frac{\Delta P}{\Delta V}=I_{p v}+V_{p v}\left(\frac{\Delta I}{\Delta V}\right)
\end{aligned}
$$

Where, $\Delta \mathrm{I} / \Delta \mathrm{V}=-\mathrm{Ipv} / \mathrm{Vpv}$ for MPP

$$
\begin{aligned}
& \Delta I / \Delta V>-\mathrm{Ipv} / \mathrm{Vpv} \text { for left of MPP } \\
& \Delta \mathrm{I} / \Delta \mathrm{V}<-\mathrm{Ipv} / \mathrm{Vpv} \text { for right of MPP }
\end{aligned}
$$

In this method the value of $\Delta \mathrm{I} / \Delta \mathrm{V}$ is compared with Ipv/ $\mathrm{Vpv}$ instantaneously, in this way the panel operating voltage is to increase or decrease until the maximum power point is attained. The behavior of Inc algorithm is not like as $\mathrm{P} \& \mathrm{O}$ algorithm, it stops adjusting when the maximum power point is reached.

\subsection{CVC MPPT technique}

The adjustment in the reference voltage $\mathrm{V}_{\mathrm{REF}}$ is done by using the CVC method. The reference voltage is changed according to the climatic variations [22, 23]. If there are any changes found in environmental conditions, then it is detected in the CVC method and the alterations are done accordingly. Due to the variations caused in the environmental conditions, the tracking seems to be critically not possible. The DC-DC converter is designed in such a way that the open-circuit voltage is sampled with the interruption of the source in the circuit. In the experiment, the circuit takes the sample of Voc in every 20 min. After 20 min. the load will be disconnected for 100 millisecond from the supply. In this time the circuit takes the new value of Voc and set the Vref accordingly (Appendix A). The main steps of flow chart for CVC method are shown in figure 4 .

$$
\frac{V_{r e f}}{K}=V_{o c}
$$

Using this equation, the value of $\operatorname{Voc}=18.18$ volt which is predefined panel voltage, $\mathrm{K}=0.80$ and $V_{R E F}=18.18 \times 0.80$ is used in the hardware circuit.

The main steps of the CVC method are given below.

Brief steps of flowchart are given as:

First of all the value of Vref will be calculated by using the value of Voc and then 


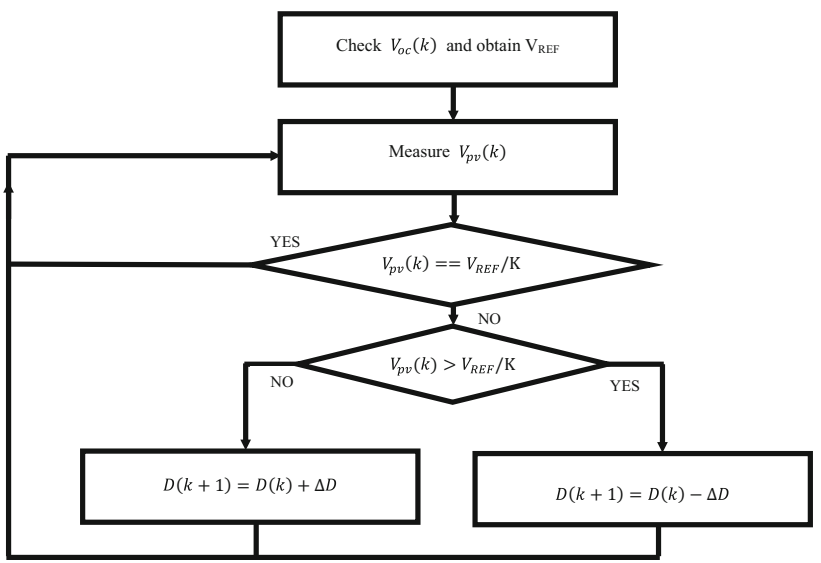

Figure 4. Flowchart of CVC method.

(i) Measure $\mathrm{V}_{\mathrm{PV}}(\mathrm{k})$

(ii) If the $\mathrm{V}_{\mathrm{REF}} / \mathrm{K}==\mathrm{V}_{\mathrm{PV}}(\mathrm{k})$, restart the loop, else check

$$
V_{P V}(\mathrm{k})>V_{R E F}
$$

(iii) If $V_{P V}(\mathrm{k})>V_{R E F}$, decrease the voltage by decreasing the duty cycle and measure the voltage Vpv, else increase the voltage by increasing the duty cycle and measure the voltage Vpv.

Now after all the steps are completed then the output if given as the feedback for measuring the voltage. The main disadvantage of this method is that the mpp is not always set on $80 \%$ of Voc, so the maximum power is wasted.

\subsection{Reference power (Pref) MPPT technique}

In this method, the variable step size is added with the input voltage as shown in Eq. (6)

$$
V_{\text {in }}(k)=V_{\text {in }}(k-1) \pm N * \frac{\text { Pref }-P_{r}}{\text { Pref }}
$$

Where $P_{r}$ is the instantaneous real power which is defined as $P_{r}=I_{p v} \times V_{p v}$.

In this method the reference power Pref is to be delivered to load. Now this $\frac{\text { Pref }-P_{r}}{\text { Pref }}$ gives a variable step size which helps to reach the MPP faster than the other MPPT methods and helps to control the power transferred to the load. The flow chart of Pref method is shown in figure 5. If the value of $\mathrm{N}$ (scaling factor) is selected on higher side, then it achieves the MPP value very fast with large ripples. If the value of $\mathrm{N}$ is less, the ripple is less but the time to achieve MPP is more. In this method the value of $\mathrm{N}=2$ has been used. In this MPPT method it is possible that the load current oscillates near the value of required current, and depends on scaling factor and step size and some time goes high from the required value. At this stage the operating point is shifted from the MPP. The main feature of this

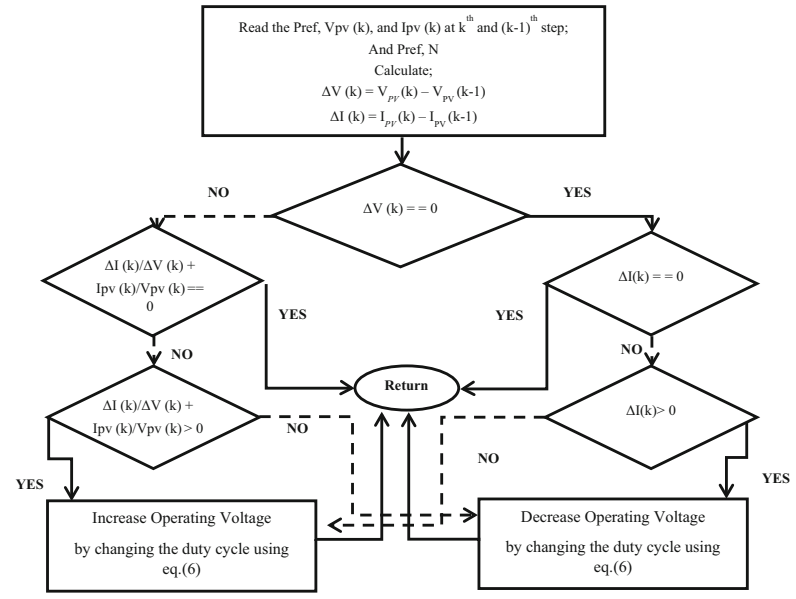

Figure 5. Main steps in flow chart of Pref method.

method is that when the required power is achieved the value of Pref- $\mathrm{P}$ becomes zero, in this way the oscillation will also die down and the value of load current will be stabilized.

Brief steps of flowchart are given as

(i) Measure $P, \operatorname{Pref}, N, \operatorname{Vpv}(k), \operatorname{Ipv}(k)$ at $K^{\text {th }}$ and $(\mathrm{K}-1)^{\text {th }}$ time; and calculate $P_{r}=\mathrm{V}(\mathrm{k}) \times \mathrm{I}(\mathrm{k})$.

(ii) Check $\Delta \mathrm{V}(\mathrm{k})$, if $\Delta \mathrm{V}(\mathrm{k})==0$; check current, continue, Else: move to step 4.

(iii) Check $\Delta \mathrm{I}(\mathrm{k})$, If $\Delta \mathrm{I}(\mathrm{k})==0$; system is stable. Move back to step 2, Else: check $\Delta \mathrm{I}(\mathrm{k})$. If $\Delta \mathrm{I}(\mathrm{k})>0$ : decrease the operating voltage, based on Pref (equation 6). Move to Step 2, Else: increase the operating voltage, based on Pref equation. Move to step 2.

(iv) Check $\Delta \mathrm{I}(\mathrm{k}) / \Delta \mathrm{V}(\mathrm{k})+\mathrm{Ipv}(\mathrm{k}) / \mathrm{Vpv}(\mathrm{k})=0$ : system is stable and move back to step 2. Else: check $\Delta \mathrm{I}$ (k) $/ \Delta \mathrm{V}(\mathrm{k})+\operatorname{Ipv}(\mathrm{k}) / \mathrm{Vpv}(\mathrm{k})>0$ : Increase the operating voltage, based on Pref equation and move to step 2; Else: decrease the operating voltage based on Pref equation. Move to step 2.

Advantages of the proposed method are of two-folds.

1) Once MPP is estimated based on this method, Set Pref $=$ power at MPP. This would allow an even faster MPP achievement rate and reduction in unstability in maintaining MPP.

2) A lower value of Pref may also be chosen, which may allow the system to provide a power lesser than MPP. This could help to establish a specified power.

\subsection{Mathematical model}

The voltage of a PV solar cell is represented by equation (7) [24] as 


$$
V_{p v}=\frac{n k T_{c}}{q} \ln \left(\frac{I_{L}+I_{s}-I_{p v}}{I_{s}}\right)-R_{s} I_{p v}
$$

To calculate the total array voltage, it is multiplied with the total number of cells which are connected in series solar panel. The total current is equal to the sum of individual current flows in the cell which are connected across each other. The output voltage and current of PV system reliant on quantities that vary with the change in atmospheric conditions which affect the output power of solar panel.

Enrique [25] has described a simplified exponential relationship between output voltage and current of PV cell.

$$
\begin{gathered}
I_{p v}=n_{p}\left[I_{L}-I_{S}\left[e^{q\left(\frac{V_{p v}}{n_{s}}+\frac{I_{p v R_{S}}}{n_{P}}\right) / n k T_{c}}-1\right]-\frac{\frac{V_{p v}}{n_{S}}+\frac{I_{p v} R_{S}}{n_{P}}}{R_{S h}}\right] \\
P=I_{p v} \cdot V_{p v} \\
P=n_{p} \cdot V_{p v} \cdot\left[I_{L}-I_{S}\left[e^{q\left(\frac{V_{p v}}{n_{S}}+\frac{P \cdot R_{S}}{p_{p v}}\right) / n k T_{c}}-1\right]-\frac{\frac{V_{p v}}{n_{S}}+\frac{P \cdot R_{S}}{V_{p v} \cdot n_{P}}}{R_{S h}}\right] \\
\left(\frac{d P}{d V_{p v}}\right)_{M P P}=0
\end{gathered}
$$

Equation (8) is used to obtain the power generated by solar panel and shown in Equations (9) and (10).The I-V curve of photo-voltaic solar cell depends on incident irradiance and cell temperature. The maximum power point provides the optimal operation point for an efficient use of the panel.

\subsection{Hardware circuit description of Inverse-Sepic converter}

The circuit diagram is shown in figure 6. As it is a DC-DC converter, which produce regulated and stepped up or down output voltage is produced. The Inverse-Sepic converters are used for maximizing the harvest energy from photovoltaic systems. So the Inverse-Sepic converters are called as power optimizers [26-28]. In this paper, the INVERSESEPIC converter is designed and controlled using a PIC microcontroller. These types of converters are used in certain type of loads like light emitting diode. The Inverse-

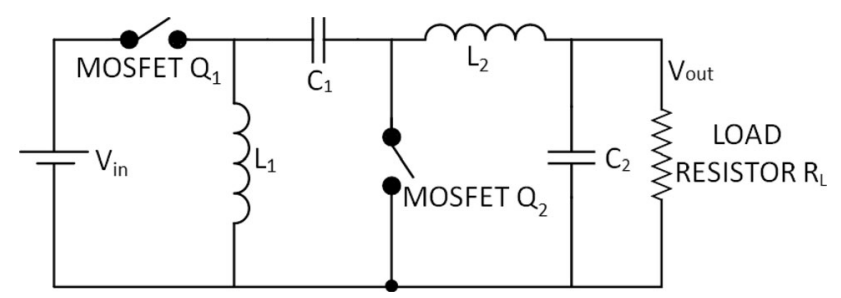

Figure 6. Circuit diagram of Inverse-Sepic converter.
In sepic converter, $\mathrm{Q}_{1}$ (MOSFET 1) and $\mathrm{Q}_{2}$ (MOSFET 2) are two switches which operate in opposite phase. When $\mathrm{Q}_{1}$ is on as a switch then current starts to flow through the primary inductor $\mathrm{L}_{1}$, load, $\mathrm{C}_{1}$ (coupling capacitor) and inductor $L_{2}$. When $Q_{2}$ is turned on, the energy stored in the $\mathrm{L}_{2}$ inductor is delivered to the load. The energy stored in inductor $\mathrm{L}_{1}$ will be zero through the capacitor $\mathrm{C}_{1}$. The current flow continuously through the load is supplied by the inductor $\mathrm{L}_{2}$.

On state equations are given as,

$$
\begin{gathered}
V_{L 1}=V_{\text {in }} \\
V_{L 2}=V_{\text {in }}+V_{c 1}-V_{\text {out }} \\
\text { Off state } \mathrm{V}_{\mathrm{L} 1}=-\mathrm{Vc1} \\
V_{L 2}=-V_{\text {out }}
\end{gathered}
$$

\section{Simulation model and result}

The Matlab simulation model of MPPT using all four methods are shown in figure 7. Matlab 14b, 64 bit version is used to solve the system model. The Ode23s (stiff/Mod. Rosen Brock) solver is used for this purpose.

This circuit topology uses a sepic converter with buckboost operation, but it delivers the continuous output current which is clean and low -ripple output current.

The output of load current (Matlab Model) for Inc method, P\&O method, constant voltage control method, Pref method are shown in figure 8(a), figure 8(b), figure $8(\mathrm{c})$, figure $8(\mathrm{~d})$, respectively. The irradiance is kept constant at $1000 \mathrm{~W} / \mathrm{m}^{2}$. The load current in Pref method is settled at $1.069 \mathrm{amp}$ in $543 \mathrm{msec}$ which is shown in figure 8(d). The load current in CVC method is settled at $1.025 \mathrm{amp}$ in $75.4 \mathrm{msec}$ which is shown in figure 8(c). The load current in Inc method is settled at $1.049 \mathrm{amp}$ in 1.253 sec which is shown in figure 8(a) and in case of $\mathrm{P} \& \mathrm{O}$ method the load current is settled at $1.014 \mathrm{Amp}$ at $1.14 \mathrm{sec}$ as shown in figure $8(b)$.

\subsection{Schematic of Inverse-Sepic converter}

The schematic of Inverse-Sepic is shown in figure 9. It has two low voltage surface mount device (SMD) and metal oxide field effect transistor (MOSFET), one of which is connected in parallel and other is connected in series with load. The circuit consists of two inductors, one inductor is used for boost operation and other inductor performs buck operation in the circuit. The circuit works in continuous conduction mode $(\mathrm{CCM})$ mode. $\mathrm{Q}_{1}$ is on during first cycle due to which current flows in the inductor $\mathrm{L}_{1}$ and by the load through the inductor $L_{2}$ and coupling capacitor $C_{1}$. When $\mathrm{Q}_{2}$ is on in the second cycle then energy stored in the 


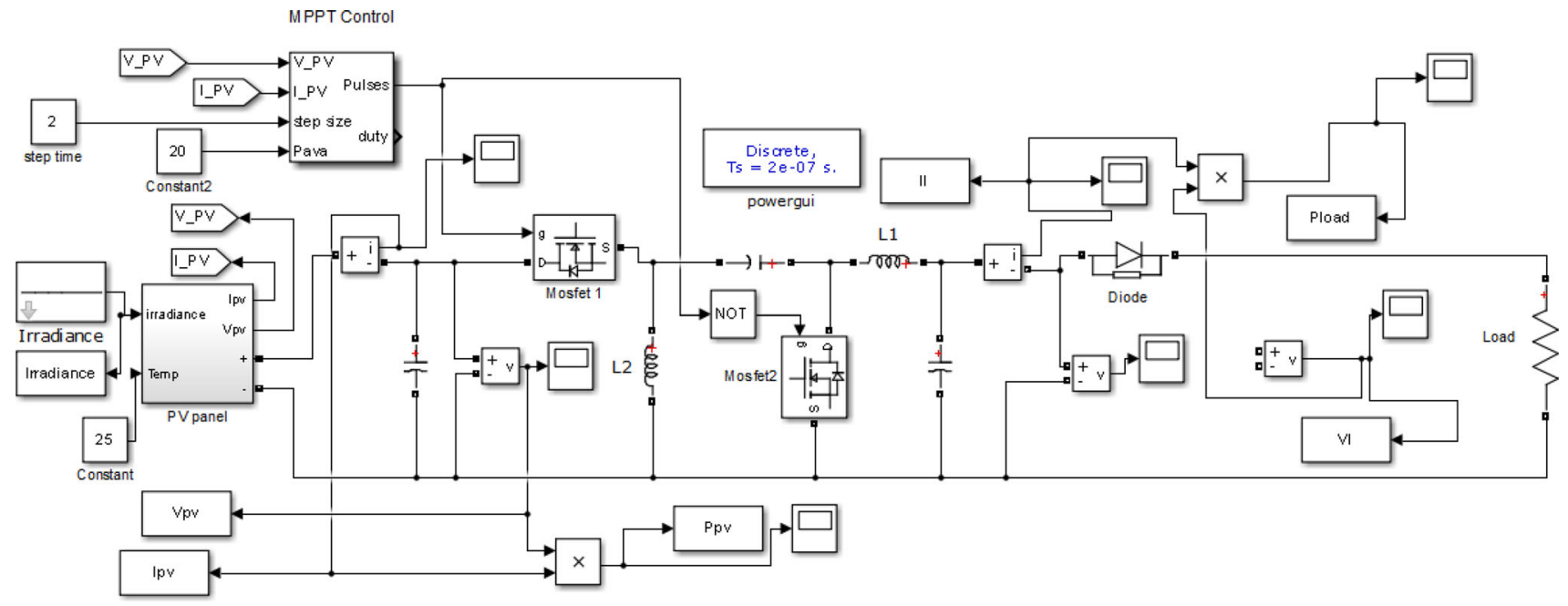

Figure 7. Simulation model of complete system.

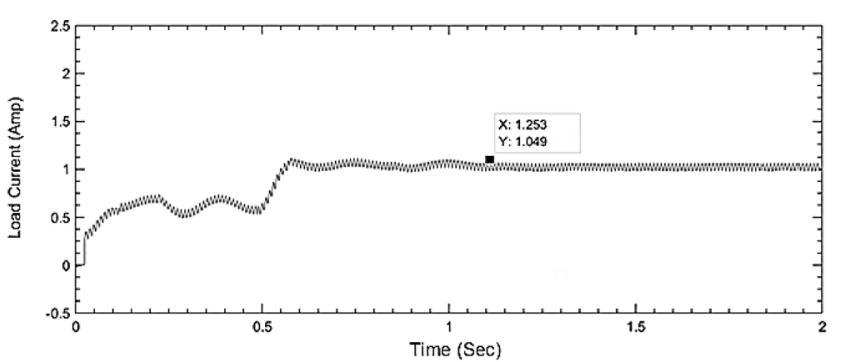

(a) Inc Method

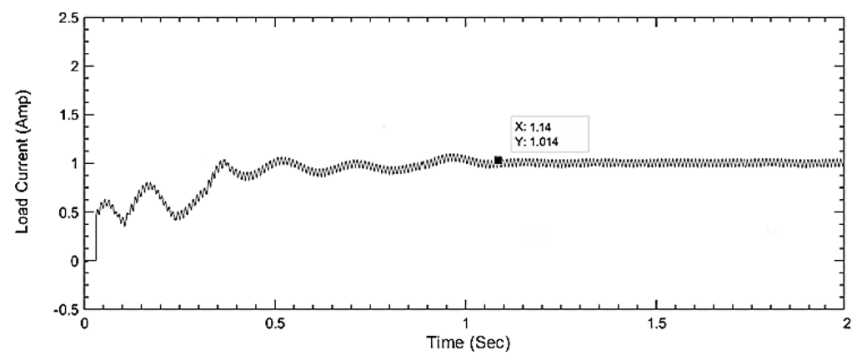

(b) P\&O method

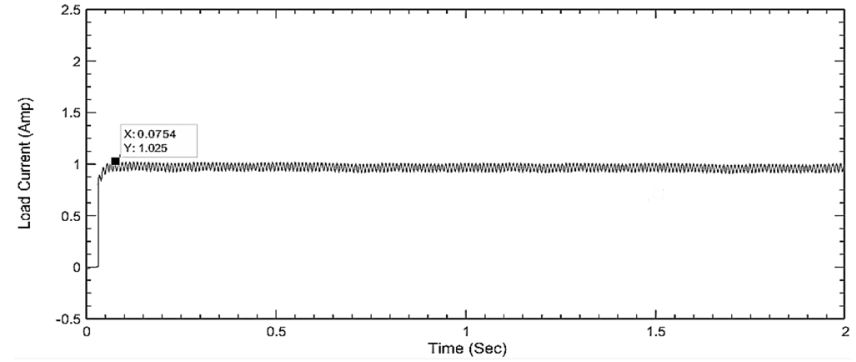

(c) CVC Method

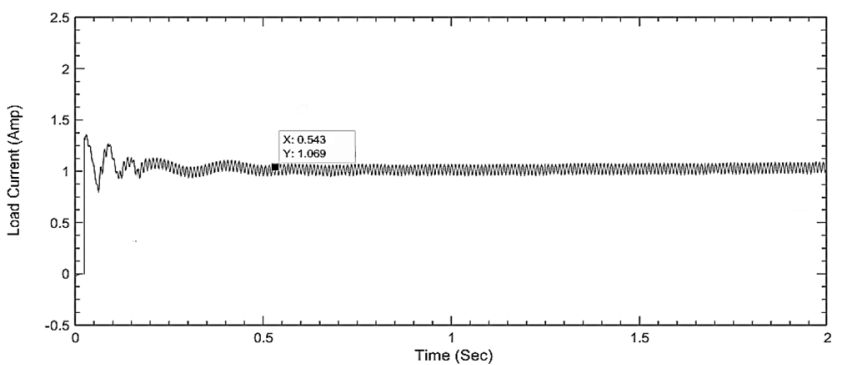

(d) Pref method

Figure 8. Load current of different MPPT methods.

inductor $\mathrm{L}_{2}$ is delivered to the load. A coupling capacitor $\mathrm{C}_{1}$ is used to set the inductor $\mathrm{L}_{1}$ to its primary value.

The inductor $\mathrm{L}_{2}$ gives nonstop current to the load. On account of the SEPIC converter the summation of input and output voltages appear across $\mathrm{Q}_{1} \cdot \mathrm{Q}_{1}$ offers the higher switching loss because of higher voltage strain over the switch. Since the inductors use common magnetic core, their magnetic coupling is evident in terms of mutual induction. It will make the total inductance increased by twice the value resulting in reduced ripple current. In order to decide the DC transfer function (transformation ratio), the volt-second adjust technique is exploited. Here the converter work in Continuous Conduction Mode (CCM) and achieves the stable state [29]. The circuit operates in buck mode when the duty cycle is under $50 \%$ and as a boost converter when it works for above $50 \%$ duty cycle.

As it is needed to charge the bootstrap capacitor, in a synchronous rectifier MOSFET the drain connection is used for phase pin. The gate of the main MOSFET $Q_{1}$ is driven by isolation capacitor. The gate and source of main 


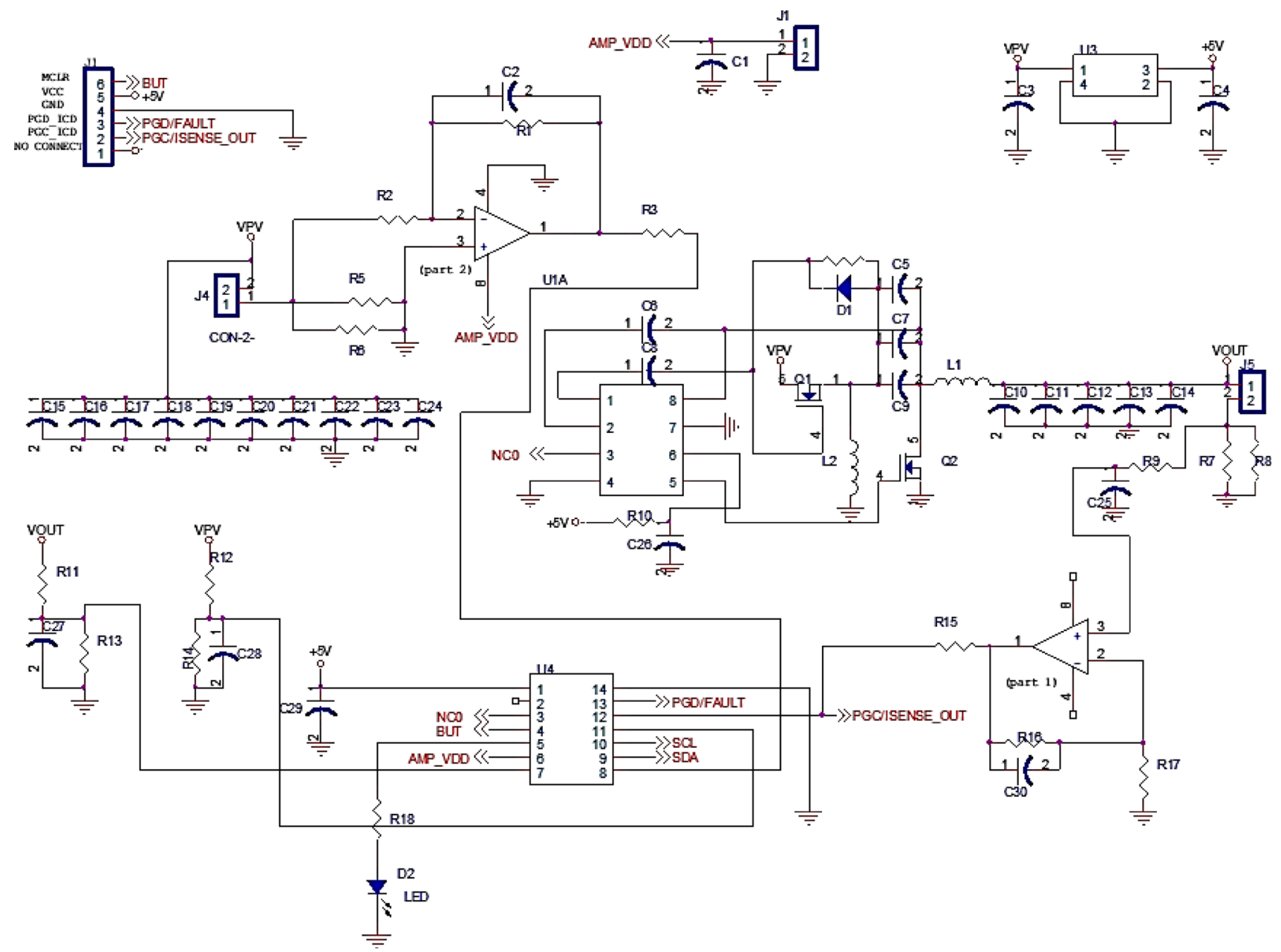

Figure 9. Schematic of Inverse-Sepic converter.

MOSFET is fully separated from the MOSFET $\mathrm{Q}_{2}$ driver. The PIC microcontroller is used to control the operation of MOSFETs. The dumbbell inductors are used for making both inductors. The polarized and non-polarized capacitors are used for storage and tuning purpose. The two connectors are separately provided for input and output purpose, one extra connector for $5 \mathrm{~V} \mathrm{dc}$ output (optional). The over voltage and under voltage lockout conditions are provided for circuit protection. The circuit will check the maximum power in every $25 \mathrm{~ms}$.

\section{// Every 25ms track Mppt point if (MpptVar.MpptCycCnt $==$ CLEAR $)$}

The soft-start is also provided for proper turn on of the circuit

Delay_ms(300);

// Give $300 \mathrm{~ms}$ power on delay for stabilization

\subsection{PCB design with legend}

This printed circuit board (PCB) layout is designed in OrCAD tool. The double side PCB who's Die positive and Die negative are shown in figures 10(a) and (b), respectively. The PCB circuit design with legend is shown in figure $10(\mathrm{c})$. Most of the components are SMD, in which all the resistors are $1 \%$ tolerance.

\subsection{Hardware and components}

The real hardware circuit of Inverse-Sepic converter is shown in figure 11, which consists of capacitors and inductors at input-output stages along with power (surface mount device) SMD MOSFETs $\mathrm{Q}_{1}$ and $\mathrm{Q}_{2}$ whose $\mathrm{V}_{\mathrm{DS}}=40 \mathrm{~V}, \mathrm{R}_{\mathrm{DS}(\mathrm{ON})}=0.0040 \Omega$ at $\mathrm{V}_{\mathrm{GS}}=4.5 \mathrm{~V}$ and $\mathrm{I}_{\mathrm{D}}=34 \mathrm{Amp}$. The switching frequency is $10 \mathrm{KHz}$. The package of MOSFET is SO-8. A fourteen pin PIC 

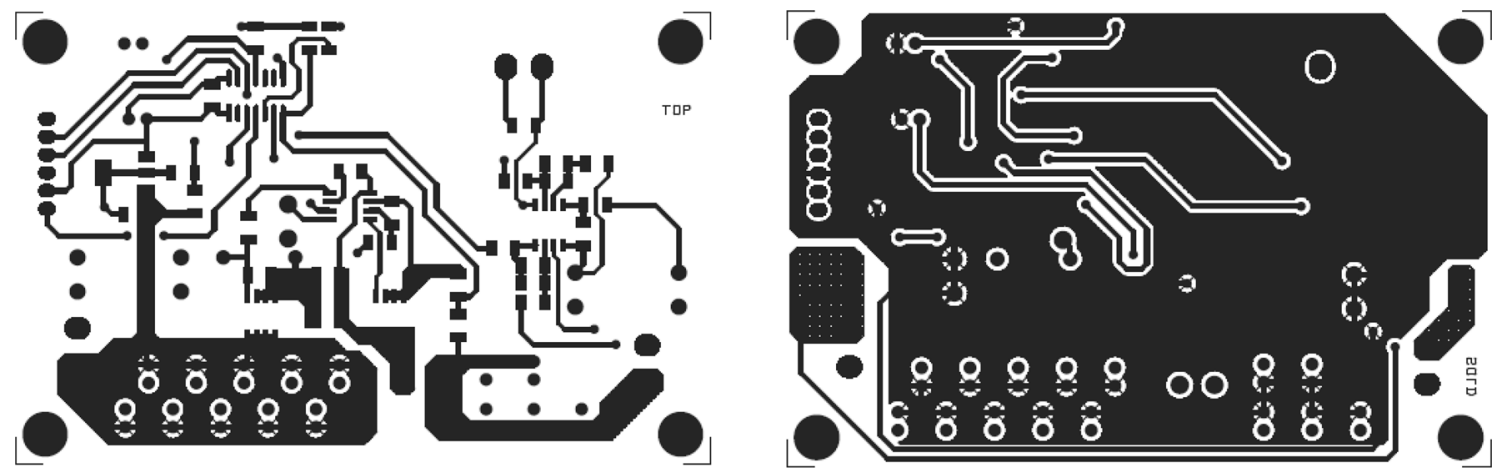

(a)

(b)

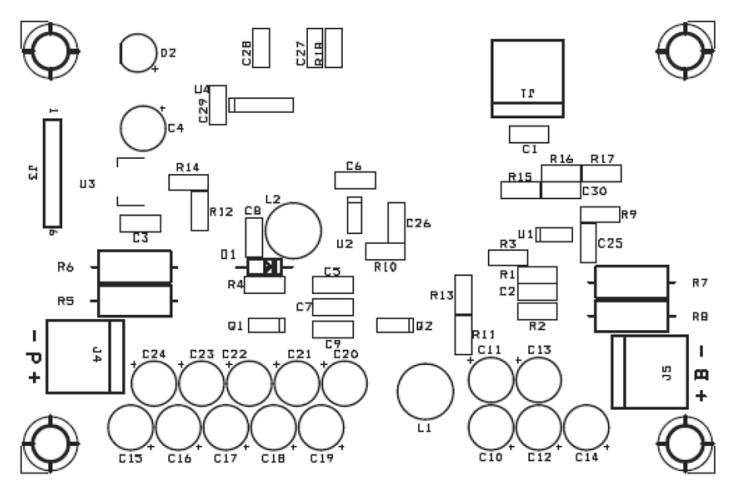

(c)

Figure 10. PCB patterns.

microcontroller is used for controlling of MOSFETs. The coupling capacitor $\left(\mathrm{C}_{1}\right)$, connected in parallel with $\mathrm{C}_{2}$, and is charged to the output voltage level. The inductors $\mathrm{L}_{1}=30.4 \mathrm{mH}$ and $\mathrm{L}_{2}=80.2 \mathrm{mH}$ are used as energy storage elements.

The value of MPPT interval is $25 \mathrm{msec}$ and oscillator frequency is $16 \mathrm{MHz}$ and the value of NCO clock is 500 $\mathrm{KHz}$ means $2 \mu \mathrm{sec}$ On Time. The value of output voltage of converter is 14.4 volts. The specifications of hardware are given in table 1. In this method, the Power $\left(\mathrm{V}^{*} \mathrm{I}\right)$, So that the algorithm will track MPPT even if $\Delta \mathrm{V}=0$, because $\Delta \mathrm{I}$ will effect $\Delta \mathrm{P}$. Pref has a constant value. It is defined by the user, which depends on panel specifications. Here, the value of Pref has been calculated which is equal to the value at MPP. The voltage at MPP is specified at $80 \%$ of VOC for the solar panel under consideration, it means voltage at MPP is $0.80 \times 18.18 \mathrm{~V}$ panel $=14.55 \mathrm{~V}$. The panel maximum current is $1.1 \mathrm{~A}(90 \%$ of short circuit current). So Pref (Ref power) $=16 \mathrm{w}$ (Appendix B). When the value of real power is equal to Pref, then the circuit will be stabilized. Otherwise, it will adjust near MPP. The value of Pref is independent from ambient condition. In equation (6), term $\mathrm{N}$ (Pref-Pr)/Pref has the maximum value as 2

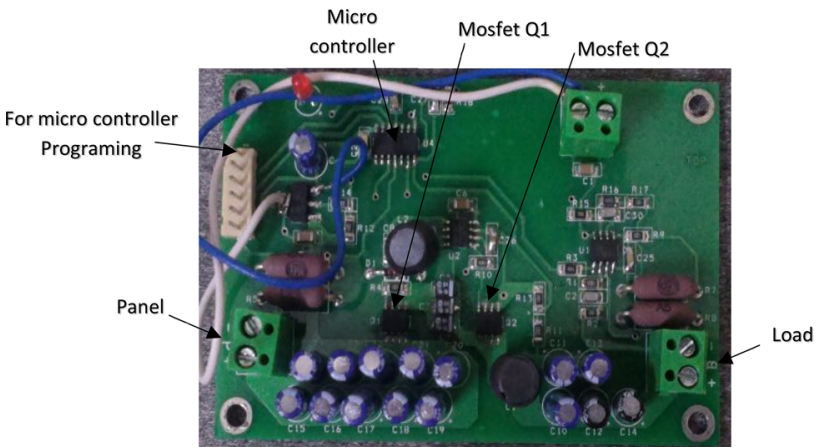

Figure 11. PCB circuit of Zeta converter.

when $\operatorname{Pr}$ is 0 and the minimum value is 0 when Pref is equal to $\operatorname{Pr}$. The value of $\mathrm{N}=2$ provides the stable value with lower oscillations so the circuit has been operated on this value (for calculation of scaling factor see Appendix C). For current and voltage sensing in real time, SMD resistors are provided (Appendix D).The circuit will take the samples of input current and voltage in every 8 milliseconds and track the maximum power point accordingly (Appendix E). 
Table 1. Hardware system specification.

\begin{tabular}{|c|c|c|}
\hline $\begin{array}{l}\text { Sl. } \\
\text { No }\end{array}$ & Circuit Item & Specification \\
\hline 1 & $\begin{array}{c}\text { DC-DC Inverse-Sepic } \\
\text { converter }\end{array}$ & $\begin{array}{c}\mathrm{V}_{\mathrm{L}}(\text { output voltage })=14.4 \\
\text { Volt } \\
\mathrm{V}_{\text {input range }}=9-20 \text { Volt } \\
\mathrm{I}_{\mathrm{L}}=1.11 \text { Ampere (max) } \\
\mathrm{P}_{\mathrm{L}}=16 \text { Watt (max) } \\
\mathrm{V}_{\text {input }}<14.4 \text {, boost operation } \\
\mathrm{V}_{\text {input }}>14.4 \text {, buck operation } \\
\text { Pref }=16 \text { Watt, } \mathrm{N} \text { (scaling } \\
\text { factor) }=2\end{array}$ \\
\hline 2 & Solar PV Panel & $\begin{array}{c}\text { Open Circuit voltage } \\
\text { Voc }=18.18 \text { Volt } \\
\text { Isc }=1.23 \mathrm{Amp} \\
\text { Vmpp }=14.55 \mathrm{Volt} \\
\text { Impp }=1.1 \mathrm{Amp}\end{array}$ \\
\hline
\end{tabular}

\subsection{Testing set-up}

The experimental results are captured using DSO model RIGOL DS11048 and performed with solar irradiance controller. In this experimental set-up the Panel rating is 18.18 Volt, which is connected to the input of Inverse-Sepic converter. The pictorial view of set-up under investigation is shown in figure 12. The output voltage of Inverse-Sepic converter is 14.4 volt. The radiation is kept at $1000 \mathrm{~W} / \mathrm{m}^{2}$ and $500 \mathrm{~W} / \mathrm{m}^{2}$ at the time of testing using the irradiation

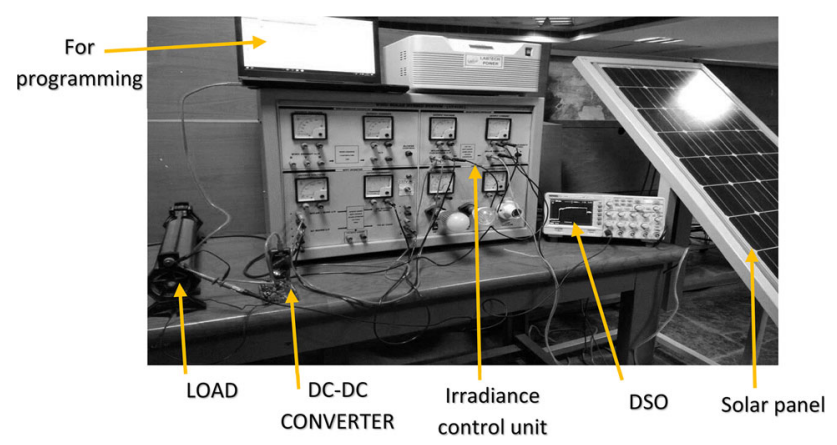

(a)

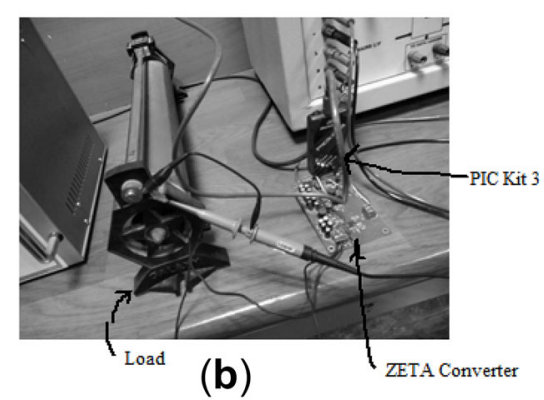

Figure 12. Testing se-tup (a) and (b). control unit. For current measurement, the resistor of $1 \mathrm{ohm}$ is connected in series with the output positive terminal of Inverse-Sepic converter. The voltage drop across these resistors is taken which comes out to be proportional to the load current (Ohm's law).The resistive load is used for the experiment purpose.

\subsection{Duty cycle}

The output voltage of converter is $14.4 \mathrm{~V}$, if the output voltage of panel is less than 14.4 volts then circuit works in boost mode and if the panel output is greater than 14.4 volts then the circuit works in buck mode. The duty cycle of Inverse-Sepic converter is adjusted in continuous current mode (Appendix F) as,

$$
\text { Vout }=\operatorname{Vin} \times(D /(1-D))
$$

Where, Vout is the output voltage which is set on (14.4 Volt) and Vin is the input voltage range ( 8 to 20 Volt) of Inverse-sepic converter. By using these values the Duty cycle will be adjusted as,

$$
\begin{aligned}
\text { At Duty } \mathrm{D}<0.5 & =\text { Buck operation } \\
\text { Duty } \mathrm{D}=0.5 & =\text { Vout is same as Vin } \\
\text { Duty } \mathrm{D}>0.5 & =\text { Boost Operation }
\end{aligned}
$$

\section{Hardware results and discussion}

The results of different MPPT methods are shown in figure 13. The results for Inc, P\&O, CVC and Pref method are shown in figures 13(a), 13(b), 13(c) and 13(d), respectively. The results are captured on different irradiation conditions $\left(500 \mathrm{~W} / \mathrm{m}^{2}\right.$ to $1000 \mathrm{~W} / \mathrm{m}^{2}, 1000 \mathrm{~W} / \mathrm{m}^{2}$ to $500 \mathrm{~W} / \mathrm{m}^{2}, 0$ to $1000 \mathrm{~W} / \mathrm{m}^{2}$ ) created by solar irradiance control unit. The MPLAB software is used to programing and load the coding in the PIC microcontroller. The pickit-3 Burner is use for loading the program.

The cursor of D.S.O is set on auto tracking mode. In figure13 (d) (i) and figure13 (d) (ii) the output current of Pref, is stabilized at $367 \mathrm{mAmp}$ in minimum time. Load side characteristics with respect to time are captured in DSO and the corresponding results are obtained for the comparison purpose and shown in table 2.

As shown in table 2, for the sudden irradiance of 1000 $\mathrm{W} / \mathrm{m}^{2}$, the load current in Pref method takes $520 \mathrm{msec}$ to stabilize at rated load current at $1.06 \mathrm{Amp}$ while Inc, P\&O, CVC methods take $1.24 \mathrm{sec}$ to achieve $1.04 \mathrm{Amp}, 1.19 \mathrm{sec}$ to achieve 1.01Amp, $75.2 \mathrm{msec}$ to achieve $1.02 \mathrm{Amp}$, respectively. The Pref method shows the higher efficiency which is $95.26 \%$ while other methods are settled down on lower efficiency in comparison with Pref method. The efficiency is calculated by using the formula $\eta=\frac{P_{o u t}}{P_{i n}}$.

The results of simulation are as shown in table 3, for sudden irradiance of $1000 \mathrm{~W} / \mathrm{m}^{2}$, the load current in Pref 


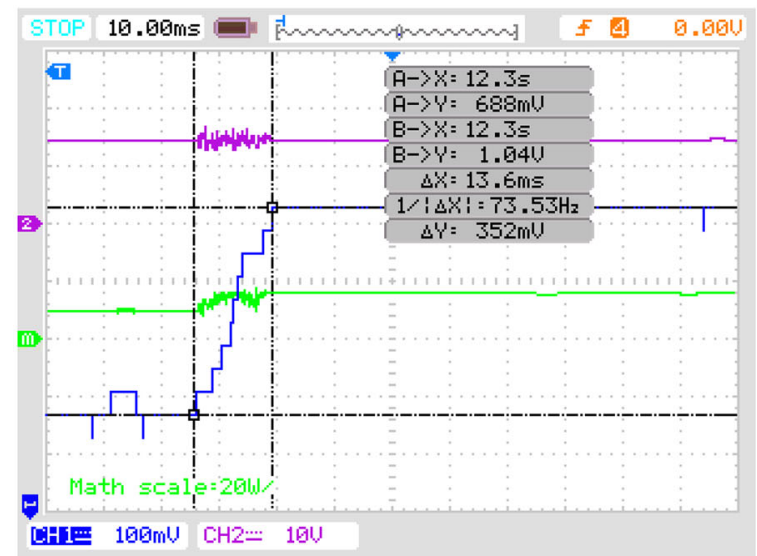

(i) Load current when irradiance raise $500 \mathrm{~W} / \mathrm{m}^{2}$ to $1000 \mathrm{~W} / \mathrm{m}^{2}$

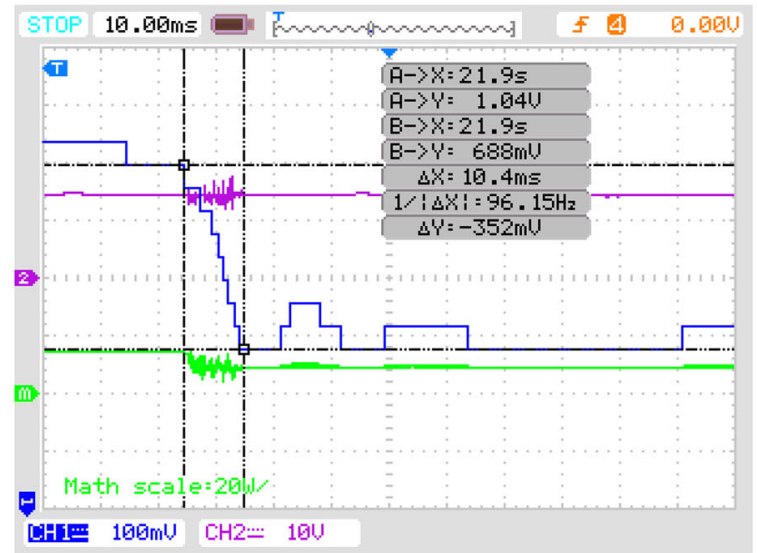

(ii) Load current when irradiance decreases $1000 \mathrm{~W} / \mathrm{m}^{2}$ to $500 \mathrm{~W} / \mathrm{m}^{2}$

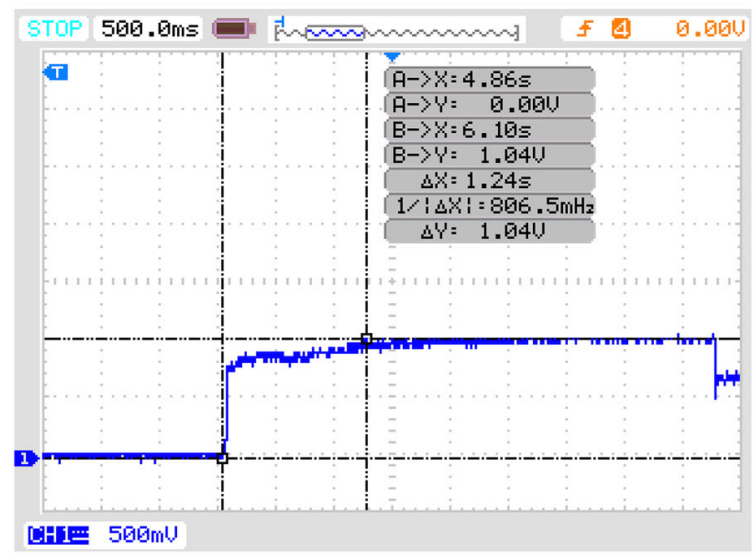

(iii) Load current when irradiance raise $0 \mathrm{~W} / \mathrm{m}^{2}$ to $1000 \mathrm{~W} / \mathrm{m}^{2}$

(a) Performance of Inc MPPT method

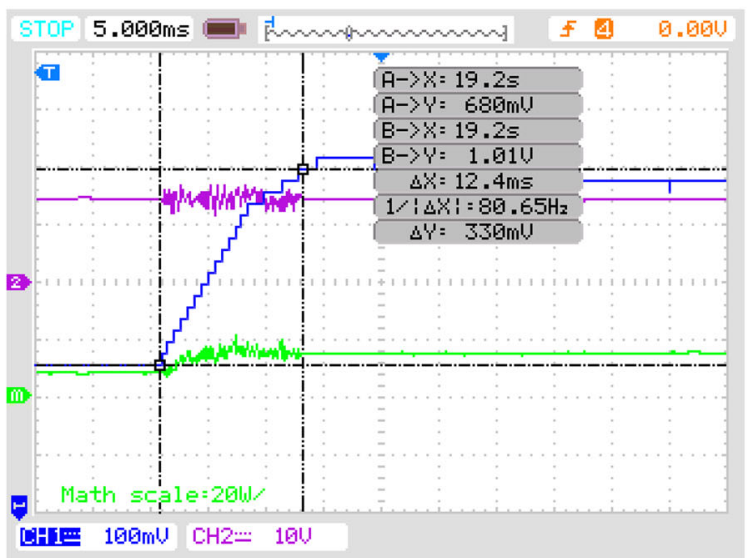

(i) Load current when irradiance raise $500 \mathrm{~W} / \mathrm{m}^{2}$ to $1000 \mathrm{~W} / \mathrm{m}^{2}$

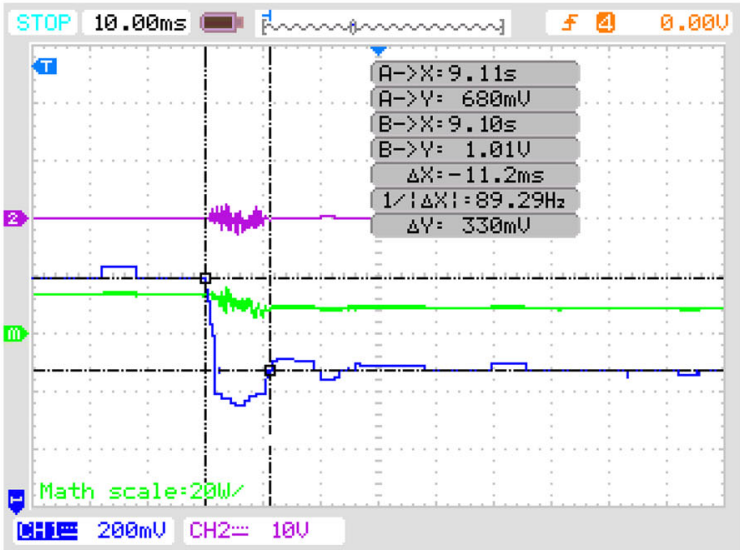

(ii) Load current when irradiance decreases $1000 \mathrm{~W} / \mathrm{m}^{2}$ to $500 \mathrm{~W} / \mathrm{m}^{2}$

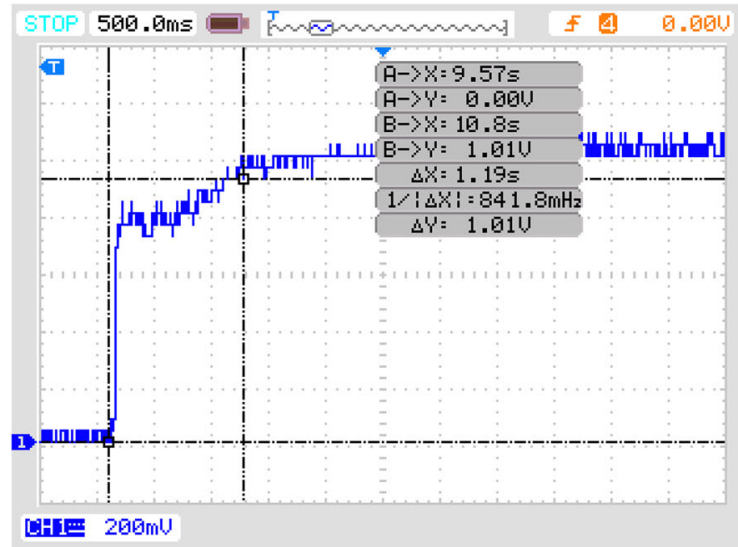

(iii) Load current when irradiance raise $0 \mathrm{~W} / \mathrm{m}^{2}$ to $1000 \mathrm{~W} / \mathrm{m}^{2}$

(b) Performance of P\&O MPPT method

Figure 13. Hardware results of different MPPT methods. 


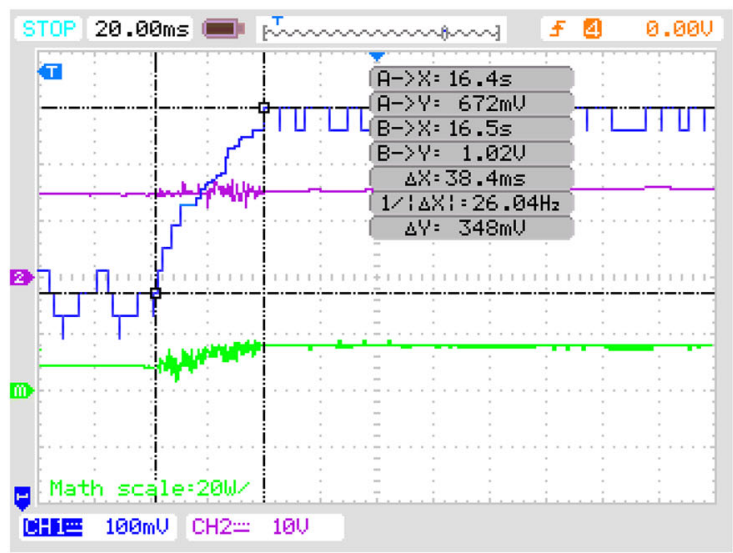

(i) Load current when irradiance raise $500 \mathrm{~W} / \mathrm{m}^{2}$ to $1000 \mathrm{~W} / \mathrm{m}^{2}$

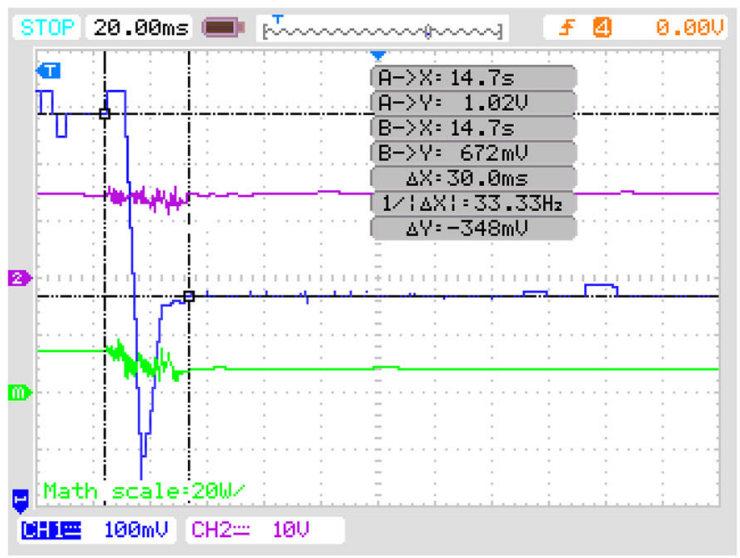

(ii) Load current when irradiance decreases $1000 \mathrm{~W} / \mathrm{m}^{2}$ to $500 \mathrm{~W} / \mathrm{m}^{2}$

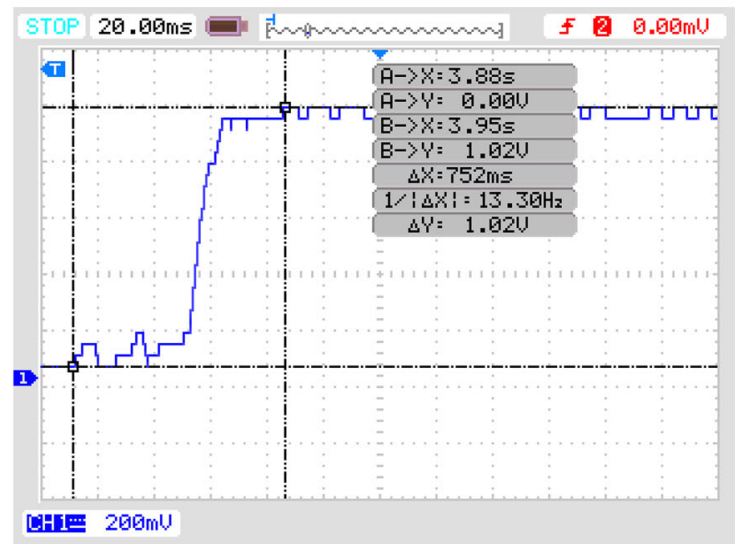

(iii) Load current when irradiance raise $0 \mathrm{~W} / \mathrm{m}^{2}$ to $1000 \mathrm{~W} / \mathrm{m}^{2}$

(c) Performance of CVC MPPT method

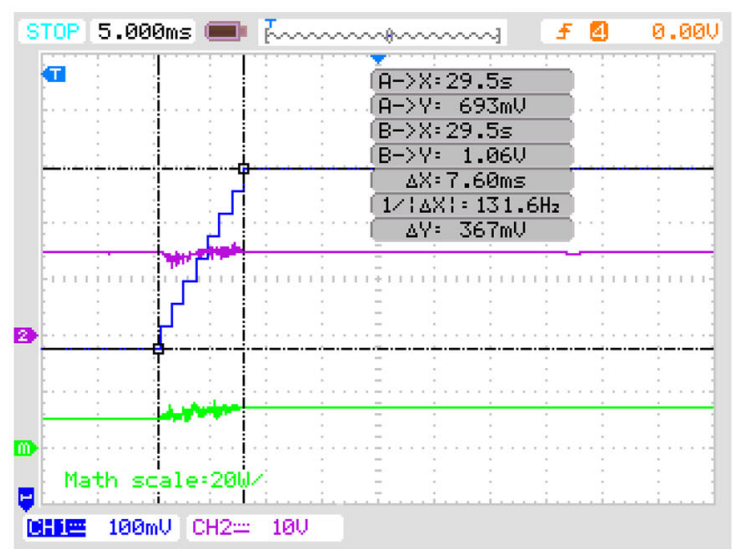

(i) Load current when irradiance raise $500 \mathrm{~W} / \mathrm{m}^{2}$ to $1000 \mathrm{~W} / \mathrm{m}^{2}$

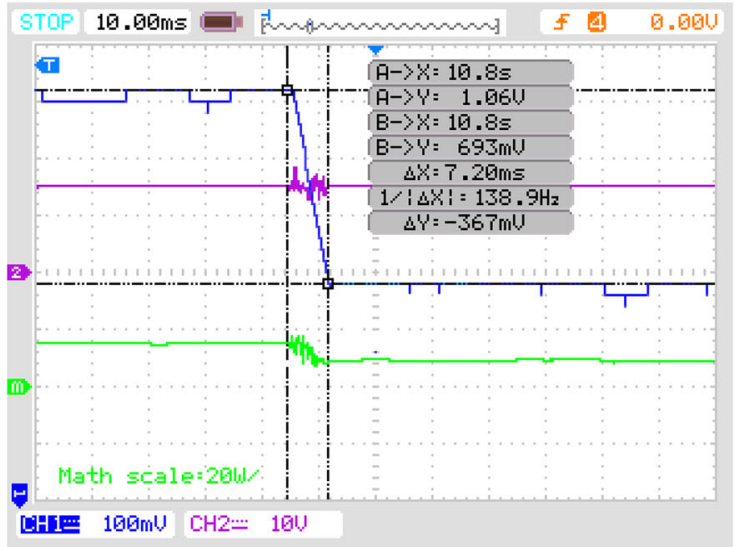

(ii) Load current when irradiance decreases $1000 \mathrm{~W} / \mathrm{m}^{2}$ to $500 \mathrm{~W} / \mathrm{m}^{2}$

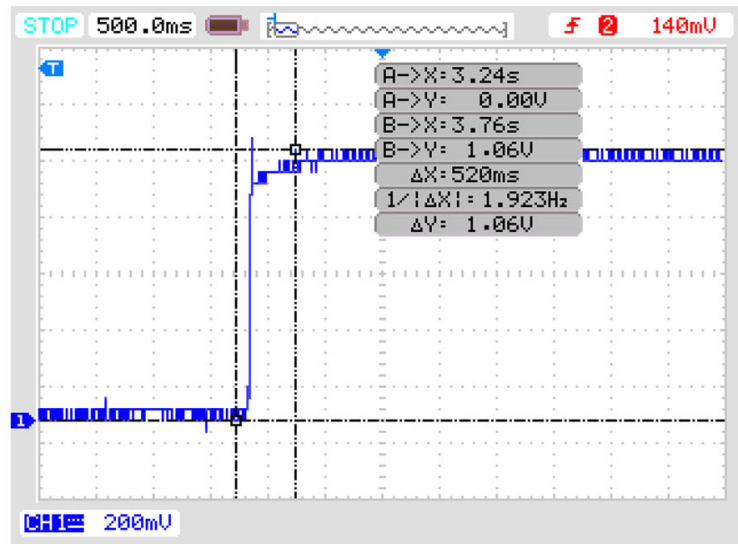

(iii) Load current when irradiance raise $0 \mathrm{~W} / \mathrm{m}^{2}$ to $1000 \mathrm{~W} / \mathrm{m}^{2}$

(d) Performance of Pref MPPT method

Figure 13. continued 
Table 2. Comparisons of experimental results for considered MPPT methods.

\begin{tabular}{|c|c|c|c|c|c|}
\hline \multirow[b]{2}{*}{$\begin{array}{l}\text { MPPT } \\
\text { Method }\end{array}$} & \multicolumn{2}{|c|}{$\begin{array}{l}\text { Settling time of output current (msec), } \\
\text { When sudden irradiance changes from } 0 \text { to } \\
1000 \mathrm{~W} / \mathrm{m}^{2} \text { is applied }\end{array}$} & \multirow[b]{2}{*}{$\begin{array}{l}\text { Output Voltage of Inverse- Sepic converter } \\
\text { (Volts) }\end{array}$} & \multirow[b]{2}{*}{$\begin{array}{l}\text { Input Power } \\
\text { (watt) }\end{array}$} & \multirow[b]{2}{*}{ Efficiency } \\
\hline & $\begin{array}{l}\text { Time } \\
(\mathrm{sec})\end{array}$ & $\begin{array}{l}\text { Output Load current(Amp)/O/P } \\
\text { Watt }\end{array}$ & & & \\
\hline Inc & 1.24 & $1.04 / 14.95$ & 14.384 & 16 & $93.43 \%$ \\
\hline $\mathrm{P \& O}$ & 1.19 & $1.01 / 14.52$ & 14.385 & 16 & $90.77 \%$ \\
\hline $\mathrm{CVC}$ & 0.752 & $1.02 / 14.66$ & 14.383 & 16 & $91.67 \%$ \\
\hline Pref & 0.520 & $1.06 / 15.24$ & 14.385 & 16 & $95.26 \%$ \\
\hline
\end{tabular}

Table 3. Comparisons of Simulink results for considered MPPT methods.

Settling time of output current (msec), When sudden irradiance changes from 0 to $1000 \mathrm{~W} / \mathrm{m}^{2}$ is applied

MPPT Method Time (sec) Output Load current(Amp)/O/P Watt Output Voltage of Inverse-Sepic converter (Volts) Efficiency

\begin{tabular}{lllll}
\hline Inc & 1.253 & $1.049 / 15.08$ & 14.386 & $94.27 \%$ \\
P\&O & 1.14 & $1.014 / 14.58$ & 14.385 & $91.13 \%$ \\
CVC & 0.0754 & $1.025 / 14.73$ & 14.385 & $92.12 \%$ \\
Pref & 0.543 & $1.069 / 15.37$ & 14.386 & $96.06 \%$ \\
\hline
\end{tabular}

Table 4. Hardware result when irradiance chances from $500 \mathrm{~W} / \mathrm{m}^{2}$ to $1000 \mathrm{~W} / \mathrm{m}^{2}$.

\begin{tabular}{|c|c|c|c|c|c|c|}
\hline $\begin{array}{l}\text { MPPT } \\
\text { METHOD }\end{array}$ & $\begin{array}{l}\text { Load current shifting (output current } \\
\text { in Amp) when irradiance changes } \\
\text { from } 500 \mathrm{~W} / \mathrm{m}^{2} \text { to } 1000 \mathrm{~W} / \mathrm{m}^{2}\end{array}$ & $\begin{array}{l}\text { Settling time of output current } \\
(\mathrm{msec}) \text { When irradiance } \\
\text { changes from } 500 \text { to } 1000 \\
\mathrm{~W} / \mathrm{m}^{2} .\end{array}$ & $\begin{array}{l}\text { Input } \\
\text { power of } \\
\text { converter } \\
\text { (watt) }\end{array}$ & $\begin{array}{l}\text { Output } \\
\text { voltage of } \\
\text { converter } \\
\text { (Volt) }\end{array}$ & $\begin{array}{l}\text { Output } \\
\text { power } \\
\text { (watt) }\end{array}$ & $\begin{array}{l}\text { Efficiency } \\
\text { of } \\
\text { converter }\end{array}$ \\
\hline Inc & $688 \mathrm{mAmp}$ to $1.04 \mathrm{Amp}$ & 13.6 & 16 & 14.383 & 14.95 & $93.43 \%$ \\
\hline $\mathrm{P} \& \mathrm{O}$ & $680 \mathrm{mAmp}$ to $1.01 \mathrm{Amp}$ & 12.4 & 16 & 14.384 & 14.52 & $90.77 \%$ \\
\hline $\mathrm{CVC}$ & $672 \mathrm{mAmp}$ to $1.02 \mathrm{Amp}$ & 38.4 & 16 & 14.383 & 14.66 & $91.67 \%$ \\
\hline Pref & $693 \mathrm{mAmp}$ to $1.06 \mathrm{Amp}$ & 7.60 & 16 & 14.382 & 15.24 & $95.26 \%$ \\
\hline
\end{tabular}

method takes $543 \mathrm{msec}$ to stabilize at rated load current at 1.069 Amp while Inc, P\&O, CVC methods take $1.253 \mathrm{sec}$ to achieve 1.049 Amp, $1.14 \mathrm{sec}$ to achieve 1.014 Amp, 75.4 msec to achieve 1.025 Amp, respectively. This shows that Pref is having the ability to settle down quickly with changing irradiance. The Pref method shows the higher efficiency which is $96.06 \%$ while other methods are settled down on lower efficiency in comparison with Pref method.

Table 4 shows the output comparison of different algorithms when irradiance rise suddenly from $500 \mathrm{~W} / \mathrm{m}^{2}$ to $1000 \mathrm{~W} / \mathrm{m}^{2}$ on solar panel. Table 4 shows the Input voltage and input power and corresponding outputs of converter when drives with different algorithms under same irradiance conditions. Under these test, the Pref algorithm is stabilized at higher value of current which is $1.06 \mathrm{Amp}$ with the efficiency of $95.26 \%$ while the other algorithms is stable at lower efficiency. When the irradiance changes from $500 \mathrm{~W} / \mathrm{m}^{2}$ to $1000 \mathrm{~W} / \mathrm{m}^{2}$, the Pref method takes only $7.60 \mathrm{msec}$ while Inc, P\&O and CVC takes $13.6 \mathrm{msec}, 12.4$ msec, $38.4 \mathrm{msec}$, respectively. This shows and validate that
Pref is having the ability to settle down quickly with changing irradiance.

Table 5 shows the output results of different algorithm when the irradiance suddenly falls from $1000 \mathrm{~W} / \mathrm{m}^{2}$ to 500 $\mathrm{W} / \mathrm{m}^{2}$. In this condition, Pref algorithm is stable at 0.693 Amp with $94.90 \%$ efficiency which is again higher when compared with other algorithms. When irradiance changes from $1000 \mathrm{~W} / \mathrm{m}^{2}$ to $500 \mathrm{~W} / \mathrm{m}^{2}$, Pref, Inc, P\&O and CVC methods take $7.20 \mathrm{msec}, 10.4 \mathrm{msec}, 11.2 \mathrm{msec}$ and 30 msec, respectively. It further shows from the results that Pref has the ability to settle down quickly under changing weather condition.

\section{Conclusions}

In this paper, the hardware and Matlab/Simulink performance of various MPPT methods implemented on InverseSepic converter was reported. Further, a MPPT tracking system based on variable step size by Pref methods was 
Table 5. Output result when irradiance chances from $1000 \mathrm{~W} / \mathrm{m}^{2}$ to $500 \mathrm{~W} / \mathrm{m}^{2}$.

\begin{tabular}{|c|c|c|c|c|c|c|}
\hline $\begin{array}{l}\text { MPPT } \\
\text { METHOD }\end{array}$ & $\begin{array}{l}\text { Load current (output current Amp) } \\
\text { when irradiance changes from } \\
1000 \mathrm{~W} / \mathrm{m}^{2} \text { to } 500 \mathrm{~W} / \mathrm{m}^{2}\end{array}$ & $\begin{array}{l}\text { Settling time of output current } \\
\text { (msec) When irradiance changes } \\
\text { from } 1000 \text { to } 500 \mathrm{~W} / \mathrm{m}^{2}\end{array}$ & $\begin{array}{l}\text { Input power } \\
\text { of converter } \\
\text { (Watt) }\end{array}$ & $\begin{array}{l}\text { Output } \\
\text { voltage of } \\
\text { converter } \\
\text { (Volt) }\end{array}$ & $\begin{array}{l}\text { Output } \\
\text { power } \\
\text { (watt) }\end{array}$ & $\begin{array}{l}\text { Efficiency } \\
\text { of } \\
\text { converter }\end{array}$ \\
\hline Inc & 1.04 Amp to $688 \mathrm{mAmp}$ & 10.4 & 10.5 & 14.378 & 9.89 & $94.19 \%$ \\
\hline $\mathrm{P} \& \mathrm{O}$ & $1.01 \mathrm{Amp}$ to $680 \mathrm{mAmp}$ & 11.2 & 10.5 & 14.372 & 9.77 & $93.04 \%$ \\
\hline $\mathrm{CVC}$ & 1.02 Amp to $672 \mathrm{mAmp}$ & 30 & 10.5 & 14.370 & 9.67 & $92.09 \%$ \\
\hline Pref & 1.06 Amp to $693 \mathrm{mAmp}$ & 7.20 & 10.5 & 14.379 & 9.96 & $94.90 \%$ \\
\hline
\end{tabular}

also proposed in this paper. The obtained results of Inc, $\mathrm{P} \& \mathrm{O}, \mathrm{CVC}$ and Pref are compared with each other and significant benefits are observed for Pref method. The rate of power delivered is maximum in case of Pref method as compared to the other methods. It is quite suitable to withstand with sudden changes in irradiation level due to its low rising time and stability of load power.

The main concluding points are as follows.

- The Simulink results of various MPPT methods implemented on Inverse-Sepic converter have been verified by experimental results.

- Load current in Pref method has been stabilized in $0.520 \mathrm{sec}$ with $1.06 \mathrm{Amp}$ current which is near to maximum current value with the highest efficiency of $95.26 \%$ for sudden exposure of $1000 \mathrm{~W} / \mathrm{m}^{2}$ irradiation level, whereas $\mathrm{P} \& \mathrm{O}$ method extracts minimum efficiency of $90.77 \%$.

- Load current in Pref method takes $7.20 \mathrm{sec}$ and 7.60 sec to stabilize for both cases, when step change in irradiance from $1000 \mathrm{~W} / \mathrm{m}^{2}$ to $500 \mathrm{~W} / \mathrm{m}^{2}$ has been applied or vice versa.

\section{List of symbols}

$\begin{array}{ll}q & \text { Electron charge }\left[1.602 \times 10^{-19} \mathrm{C}\right] \\ k & \text { Boltzmann constant }\left[1.38 \times 10^{-23} \mathrm{~J} /{ }^{\circ} \mathrm{K}\right] \\ n_{p} & \text { Number of cells connected in parallel } \\ n_{s} & \text { Number of cells connected in series } \\ n & \text { Deviation factor of the characteristics of an ideal p-n } \\ & \text { junction/Ideality constant } \\ T_{c} & \text { Cell operating temperature }\left[{ }^{\circ} \mathrm{K}\right] \\ R_{S} & \text { Series resistance of cell }(0.001 \Omega) \\ R_{s h} & \text { Intrinsic parallel resistances associated to the panel } \\ & {[\Omega]} \\ I_{p v} & \text { Panel output current }[\mathrm{A}] \\ I_{s} & \text { Reverse saturation current }[\mathrm{A}] \\ I_{L} & \text { Photo-current generated by solar radiation }[\mathrm{A}] \\ V_{p v} & \text { Panel output voltage }[\mathrm{V}]\end{array}$
$P_{r} \quad$ Real power of solar PV [W]
$D \quad$ Duty Cycle
Pref Reference power of solar PV [W]

\section{Appendix A: Voc measurement for CVC method}

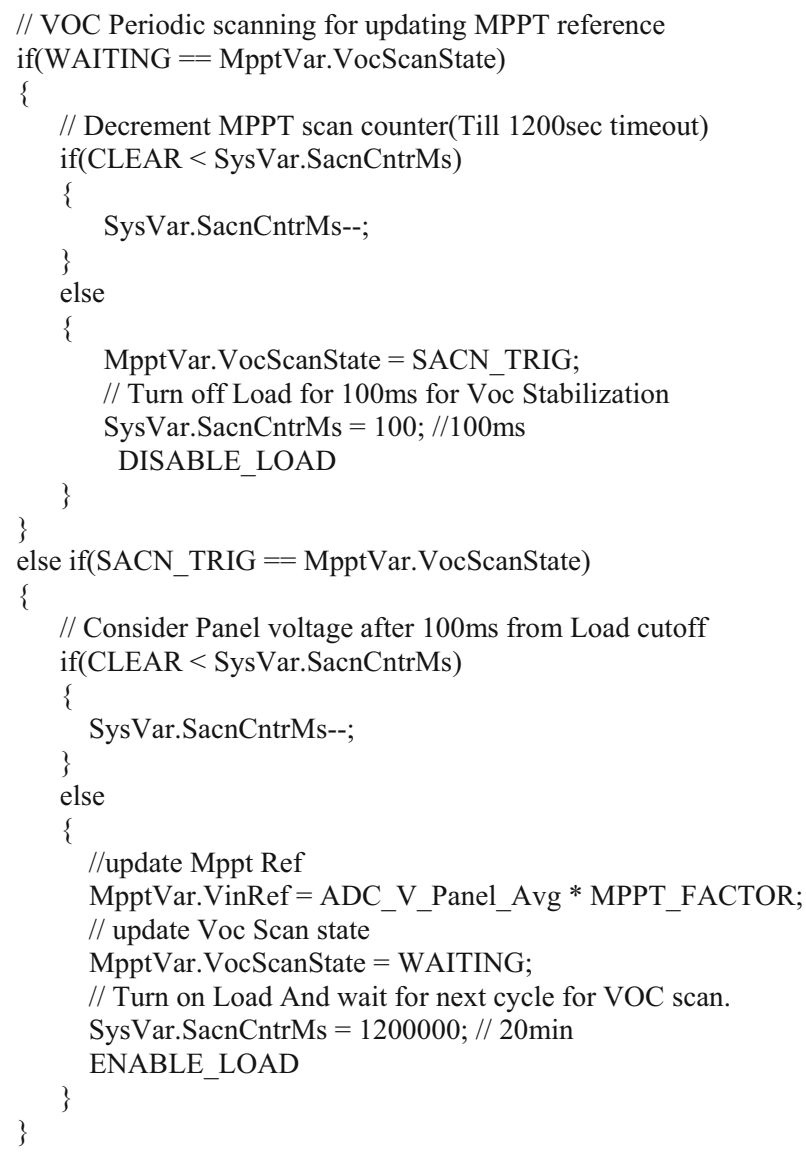

Appendix B: Calculation of Reference Power Pref

As in Code: 
\#define MPPT_REF_POWER $(2949 \times 450) / / 14.55 \mathrm{~V} \times 1.1 \mathrm{~A}$ Typically MPPT achieves at $80 \%$ of VOC of panel. $0.80 \times 18.18$

$\mathrm{v}$ panel $=14.55 \mathrm{~V}$ and panel current is $1.1 \mathrm{Amp}$. So MPPT power $($ Ref power $)=16 \mathrm{w}$.

\section{Appendix C: Calculation of scaling factor $\mathbf{N}$}

\author{
temp $=(($ temp $/$ MPPT_REF_POWER $) * 5) / 10$; \\ and \\ \#define MPPT SCALE FACTOR 640//4.0v. (640/4096*25v) \\ Vout $(\mathrm{k})=$ Vout $(\overline{\mathrm{k}}-1)+/-\overline{\mathrm{N}}(\operatorname{Pref}-\mathrm{Pr}) /$ Pref. Here Max N $=4$ and it \\ should be in Volt scale $(25 \mathrm{v}=4096$ count, $4 \mathrm{~V}=640$ count $)$. \\ $\mathrm{N}$ is MPPT SCALE FACTOR. \\ Again to tune $\mathrm{N}$ from 0 to 4 we provided scaling $\mathrm{X} / 10$. X configured as 5 . \\ So Effective $N=4 *(5 / 10)=2$.
}

\section{Appendix D: Input, output resistor for current and voltage measurement}

The sensing resistors are as follows

\begin{tabular}{|c|c|c|c|c|}
\hline S.NO & SENSE & LEGEND & $\begin{array}{l}\text { CONNECTED TO PIN NO's } \\
\text { OF MICROCONTROLLER }\end{array}$ & VALUE \\
\hline 1 & $\begin{array}{l}\text { INPUT } \\
\text { CURRENT }\end{array}$ & R3 & 8 & $\begin{array}{c}100 \Omega \pm 1 \% \\
\text { tolerance }\end{array}$ \\
\hline 2 & $\begin{array}{l}\text { OUTPUT } \\
\text { CURRENT }\end{array}$ & R15 & 12 & $\begin{array}{c}100 \Omega \pm 1 \% \\
\text { tolerance }\end{array}$ \\
\hline 3 & $\begin{array}{l}\text { INPUT } \\
\text { VOLTAGE }\end{array}$ & R14 & 11 & $\begin{array}{r}3 \mathrm{~K} \Omega \pm 1 \% \\
\quad \text { tolerance }\end{array}$ \\
\hline 4 & $\begin{array}{l}\text { OUTPUT } \\
\text { VOLTAGE }\end{array}$ & $\mathrm{R} 13$ & 7 & $\begin{array}{r}1 \mathrm{~K} \Omega \pm 1 \% \\
\text { tolerance }\end{array}$ \\
\hline
\end{tabular}

In real time the circuit read the input current by series resistor R3. The value of $\mathrm{R} 3$ is $100 \Omega \pm 1 \%$ tolerance for scaling purpose. The $\mathrm{R} 3$ resistor is connected to pin no 8 of the microcontroller. The output current is sensed by series resistor R15 of $100 \Omega \pm 1 \%$ tolerance which is connected on pin 12 of microcontroller. The Input voltage is carried out across the potential divider resistor $\mathrm{R} 14$ of $3 \mathrm{~K} \Omega \pm 1 \%$ tolerance and the output voltage is carried out across the potential divider resistor $\mathrm{R} 13$ of $1 \mathrm{~K} \Omega \pm 1 \%$ tolerance (Ref figure no. 8).

The value of sensing voltage resistor $R_{14}$ is decided by the voltage division method. The value of sensing voltage $V_{R_{14}}$ is given in data sheet.

$$
V_{R_{14}}=\frac{R_{14}}{R_{12}+R_{14}} \times V_{\text {in }} \quad(\text { Ref Fig no. } 8)
$$

Similarly the value of sensing voltage resistor $R_{13}$ is decided by the voltage division method. The value of sensing voltage $V_{R_{13}}$ is given in data sheet.

$$
V_{R_{13}}=\frac{R_{13}}{R_{11}+R_{13}} \times V_{\text {out }} \quad(\text { Ref Fig no. } 8)
$$

\section{Appendix E: MPPT point tracking program}

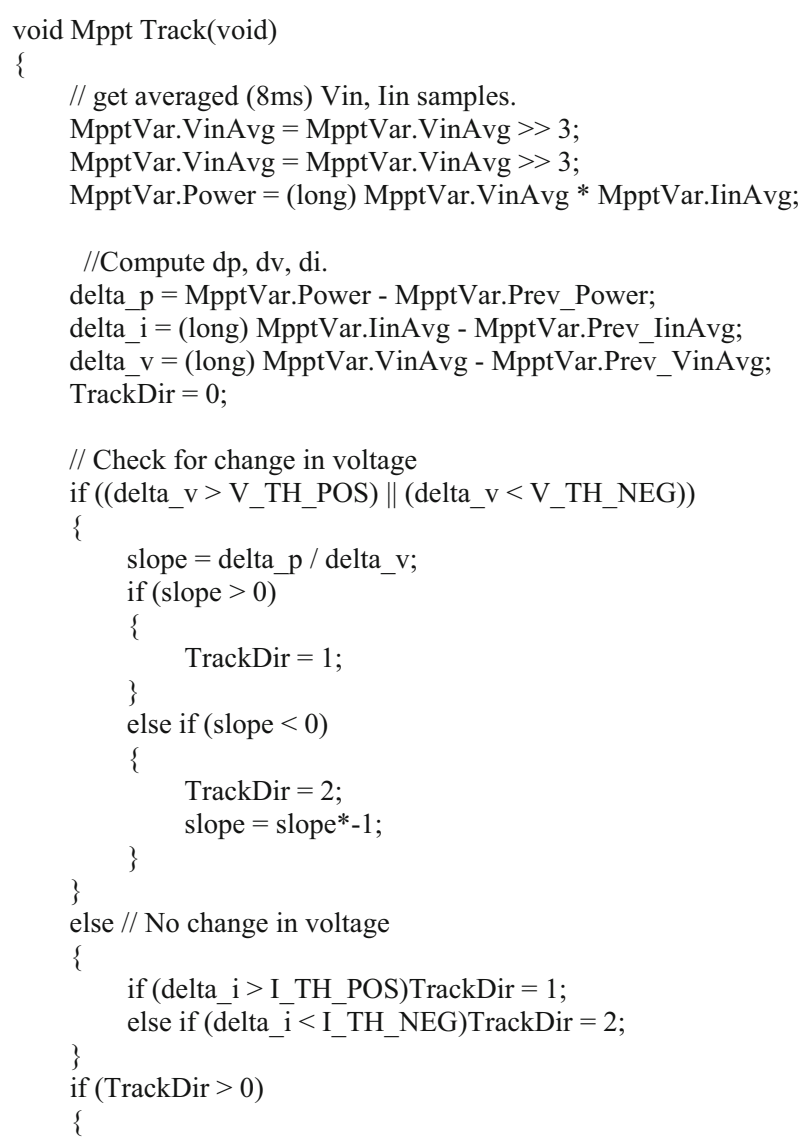

\section{Appendix F: Calculation of duty cycle}

The duty cycle is adjusted by the equation

$$
\text { Vout }=\operatorname{Vin} \times(D /(1-D))
$$

Where Vout is the voltage across the load and Vin is the input voltage of inverse sepic converter.

Where, Vin is Vin $(k)=$ Vin $(k-1)+/-N($ Pref-Pr)/Pref . By using these values the Duty cycle will adjust.

At Duty $\mathrm{D}<0.5=$ Buck operation

Duty $\mathrm{D}=0.5=$ Vout is same as Vin

Duty $\mathrm{D}>0.5=$ Boost Operation

Step based on Pref

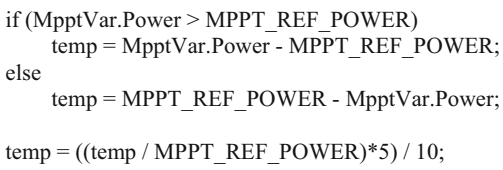

MpptVar.StepValue $=$ MpptVar.StepValue + MPPT_SCALE_FACTOR $*$ temp;

So, as per the step size, Vout will be calculated like, Vout $(\mathrm{k})=$ Vout $(\mathrm{k}-1)+/-\mathrm{N}($ Pref - Pr $) /$ Pref. 
Here $\operatorname{Max} \mathrm{N}=2$.

The increment and decrement of voltage is as follows As per Code:

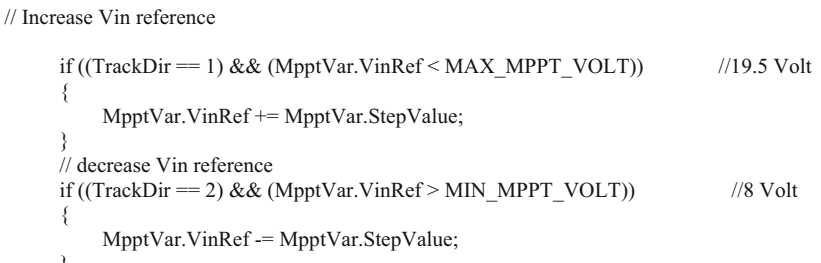

\section{References}

[1] Azevedo G, Cavalcanti M, Oliveira K, Neves F and Lins Z 2009 Comparative evaluation of maximum power point tracking methods for photovoltaic systems. J. Solar Energy Eng. 13(3): 031006

[2] Calavia M, Perie J, Sanz J and Sallan J 2010 Comparison of MPPT strategies for solar modules. In: International Conference on Renewable Energies and Power Quality 1(8):1440-1445

[3] Dahbi S, Aziz A, Benazzi N, Elhafyani M, and Benahmed N 2016. Advanced MPPT controller based on P\&O algorithm with variable step size and acceleration mechanism for solar photovoltaic system. In: Proceedings of the Mediterranean Conference on Information \& Communication Technologies 2015, pp. 57-67

[4] Dahech K, Allouche M, Damak T and Tadeo F 2017 Backstepping sliding mode control for maximum power point tracking of a photovoltaic system. Electric Power Syst. Res. 143: $182-188$

[5] De Melo Bento A, Acevedo-Bueno D and Cabral da Silva E 2016 Dual input dual output single switch DC-DC converter for renewable energy applications. In: IEEE Energy Conversion Congress and Exposition (ECCE)

[6] De Brito M, Galotto L, Sampaio L, e Melo G and Canesin C 2013 Evaluation of the Main MPPT Techniques for Photovoltaic Applications. IEEE Trans. Ind. Electr. 60(3): 1156-1167

[7] Dileep G and Singh S 2017 Application of soft computing techniques for maximum power point tracking of SPV system. Solar Energy 141: 182-202

[8] Dolara A, Faranda R and Leva S 2009 Energy Comparison of Seven MPPT Techniques for PV Systems. J. Electromagn. Anal. Appl. 01: 152-162

[9] Fathabadi H 2016 Novel fast dynamic MPPT (maximum power point tracking) technique with the capability of very high accurate power tracking. Energy 94: 466-475

[10] Fathabadi H 2017 Novel fast and high accuracy maximum power point tracking method for hybrid photovoltaic/fuel cell energy conversion systems. Renew. Energy 106: 232-242

[11] Harrag A and Messalti S 2015 Variable step size modified P\&O MPPT algorithm using GA-based hybrid offline/online PID controller. Renew. Sustain. Energy Rev. 49: 1247-1260

[12] Ishaque K and Salam Z 2013 A review of maximum power point tracking techniques of PV system for uniform insolation and partial shading condition. Renew. Sustain. Energy Rev. 19: 475-488
[13] Taghvaee M, Radzi M, Moosavain S, Hizam H and Hamiruce Marhaban M 2013 A current and future study on nonisolated DC-DC converters for photovoltaic applications. Renew. Sustain. Energy Rev. 17: 216-227

[14] Tey K and Mekhilef S 2014 Modified incremental conductance MPPT algorithm to mitigate inaccurate responses under fast-changing solar irradiation level. Solar Energy 101: 333-342

[15] Tomar R 2016 Comparison between Perturb \& Observe Method and Incremental Conductance Method for Maximum Power Point Tracking of PV Module. [online] Available at: http://dspace.thapar.edu:8080/jspui/bitstream/10266/4344/1/ Rahul_801441021.pdf

[16] Verma D, Nema S, Shandilya A and Dash S 2016 Maximum power point tracking (MPPT) techniques: Recapitulation in solar photovoltaic systems. Renew. Sustain. Energy Rev. 54: 1018-1034

[17] Priyadarshi N et al 2017 An Experimental Study on InverseSepic Buck-Boost Converter for Application in PV System. Handbook of Distributed Generation Springer International Publishing: Cham, Switzerland, 393-406

[18] Liu L, Meng X and Liu C 2016 A review of maximum power point tracking methods of PV power system at uniform and partial shading. Renew. Sustain. Energy Rev. 53: 1500-1507

[19] Ram J, Babu T and Rajasekar N 2017 A comprehensive review on solar PV maximum power point tracking techniques. Renew. Sustain. Energy Rev. 67: 826-847

[20] Ramli M, Twaha S, Ishaque K and Al-Turki Y 2017 A review on maximum power point tracking for photovoltaic systems with and without shading conditions. Renew. Sustain. Energy Rev. 67: 144-159

[21] Rezk H and Eltamaly A M 2015 A comprehensive comparison of different MPPT techniques for photovoltaic systems. Solar Energy 112: 1-11

[22] Saravanan S and Babu N R 2016 Maximum power point tracking algorithms for photovoltaic system-A review. $R e$ new. Sustain. Energy Rev. 57: 192-204

[23] Gupta CL 1993 Solar passive buildings for developing countries. Sadhana 18(1): 77-104

[24] Altas A and Sharaf A M 1991 A solar powered permanent magnet DC motor drive schem. In: Proc., Annu. Conf. Solar Energy Soc. Canada, Toronto, pp. 65-70

[25] Enrique J M, Duran E Sidrach-de-Cardona M and Andujar J M 2007 Theoretical assessment of the maximum power point tracking efficiency of photovoltaic facilities with different converter topologies. Solar Energy 81(1): 31-38

[26] Kundu U and Sensarma P 2017 Discontinuous conduction mode analysis of phase-modulated series resonant converter. Sadhana 42(8): 1299-1307

[27] Rajani SV and Pandya V 2015. Simulation and comparison of perturb and observe and incremental conductance MPPT algorithms for solar energy system connected to grid. Sadhana 40(1): 139-153

[28] Panda A, Pathak MK and Srivastava SP 2016 A single phase photovoltaic inverter control for grid connected system. Sadhana 41(1): 15-30

[29] Bharadwaj P and John V 2014 Direct duty ratio controlled MPPT algorithm for boost converter in continuous and discontinuous modes of operation. In: Power Electronics (IICPE), 2014 IEEE 6th India International Conference (pp. 1-6) 